\title{
ENVIRONMENTAL IMPACT ASSESSMENT: A COMPARATIVE ANALYSIS OF THE FEDERAL RESPONSE IN CANADA AND THE UNITED STATES*
}

\author{
SANDRA K. MCCALLUM**
}

\begin{abstract}
This article examines the planning tool known as environmental impact assessment. This tool is a decision-making model which attempts to integrate environmental considerations into each stage of the planning process together with the traditional concerns of economics and technology in order to identify secon. dary and cumulative impacts and to weigh environmental effects. The success of an assessment process depends on the capability of the chosen institutional arrangements to achieve the desired goal. The proposed federal procedure is examined and several weaknesses identified. One is the absence of legislative measures to support the process. The United States National Environmental Policy Act provides a model. This statute is discussed with a view to ascertaining whether like legislation in Canada would produce a like result. The conclusion reached is that differences between Parliamentary and Congressional systems suggest that in Canada a more appropriate course would be to adopt legislative measures which strengthen and improve the existing functions of government. Such a course would better serve the goal of environmental impact assessment than attempts to transplant concepts which are ill fitted and insensitive to the parliamentary system.
\end{abstract}

\section{INTRODUCTION}

During the last century man's activity on the earth's surface has enormously intensified. If one views the momentum of activity over the last century against the perspective of the preceding centuries it is obvious that exploitation and use of natural resources has accelerated and the potential for altering the environment in a short period is now staggering.

Together with the increased activity has evolved a greater knowledge of the physical surroundings. This knowledge has brought many to question the limits of the elasticity of our ecosystem to tolerate unchecked growth and unplanned developments. The increase in knowledge about the environment in which we operate has resulted in a growing awareness that most elements of the ecosystem are interrelated so that one seemingly innocuous activity may set off various side effects with detrimental consequences.

During the last decade, in response to demands to control the way in which resources are utilized, the governments (both federal and provincial) have enacted legislation aimed at abatement and restorative measures. ${ }^{1}$

The realization of the interrelated aspects of activities has highlighted the need for a more comprehensive consideration of environmental consequences of actions at the earliest possible stage of decision making processes.

From these realizations has developed a planning tool by the title of environmental impact assessment. It has been said that the assessment

-In its original form this article was submitted in partial fulfillment of the requirements of the LL.M. at the University of British Columbia. I wish to acknowledge with gratitude the advice of Dr. A. R. Thompson, Professors A. R. Lucas and R. Franson of the Faculty of Law and Dr. I. Fox, Director of Westwater Research Centre.

**B. Juris, LL.B. (Monash), LL.M. (B.C.). Barrister and Solicitor of the Supreme Court of Victoria. Consultant, Law Reform Commission of Canada. The views expressed are personal to the author and in no way reflect those of the Commission or the Department of Justice.

1 There are many federal and provincial statutes dealing with regulation of natural resources; e.g. Clean Air Act, S.C. 1971, c. 47; Water Act, R.S.B.C. 1960, c. 405. Parisien. R and Reuben. F. in Evaluation of En. vironmental Pre-assessment of Existing Federal Legislation. Environment Canada 1972, list 37 federal statutes dealing in some way with regulation of the environment. 
procedure is the next step in the evolutionary process from abatement and restorative measures to preventative ones. ${ }^{2}$ It is the belief of proponents of impact assessment that increased before-the-fact investigation will substantially diminish the need for abatement and restorative measures by bringing an early awareness from an environmental viewpoint which has hitherto been ignored.

The purpose of this new planning tool is to attempt an integrated consideration of the consequences of actions at the earliest possible stage of planning in order to elucidate the consequences of a particular activity while options are still open to reconsider the desirability of the action or the desirability of the mode of operation before irretrievable commitment is made.

In the past natural resources have been regulated by various government agencies whose mandate is restricted to a particular resource. The new process demands a holistic approach which acknowledges the interrelated nature of activities. It therefore will traverse traditional departmental boundaries and require greater cooperation among departments.

The interrelatedness of activities has also led to a much wider definition of environmental impact than one which describes physical features and impacts upon them. Generally when the term is used it is in the sense of the human environment and covers a wide range of social and economic issues. ${ }^{3}$

Because the term has developed into such a comprehensive one, many of the issues which any proposed procedure is designed to deal with will be involved with questions of social choice and the making of value judgments which affect cliverse interest groups. The breadth of the issues and the difficulty inherent in resolving them has led to the belief that any procedure must provide opportunity for public input to the decision making process.

There have been many proposals put forward for environmental impact assessment procedures and these will be discussed first. Although there are numerous alternative procedures which could be implemented, it is clear that common to all is the need for public involvement in the process and a means for ensuring that the procedures are adhered to by those responsible for implementing them.

In dealing with proposals for implementing procedures it is therefore of vital importance to give careful consideration to the means which will be available to enforce compliance with the procedure. The institutional arrangements available for implementing the procedure will have a substantial influence on its effectiveness. In choosing a procedure the potential of the institutional framework in which it will operate, to frustrate or to expedite the purpose, should be a major concern in choosing between modes of procedure. An analysis of the governmental structure in which the policy is to operate is part of this paper.

\section{ENVIRONMENTAL IMPACT PROCEDURES}

The procedure is designed to regulate decision-making processes in order to provide a framework in which environmental matters may be considered at the earliest possible stage of the planning process so that the trade-offs made, if a decision to proceed is taken, will be clearly seen and weighed against the traditional concerns of economics and technology.

\footnotetext{
2 Ministry of the Environment (Ontario), Green Paper on Environmental Assessment, September 1973, at 3.

- The National Envirunmental Policy Act of the United States uses the term "human environment". The Green Paper, Id. at 6 recognizes "that environmental concerns are interconnected often causally with concerns and decisions in the economic and social system."
} 
The decision-making process can be divided into three stages: firstly, the threshold question of when an impact assessment is required; secondly, who should prepare it and in what manner; thirdly, who should review the adequacy of the assessment. At each stage of the process it has been recognized that there is a need to give the public an opportunity to participate in the process.

\section{A. Public Participation}

The following purposes for encouraging public participation in an assessment procedure were identified by the Federal Task Force appointed by the Department of Environment to study environmental impact policy and procedure as follows:4

(1) Interests that are likely to be affected by environmental impacts of actions, but that are uniikely to be represented in the assessments and decision process are provided with an opportunity to participate. This is consistent with the democratic objective of an increased citizen role in public decision making and with the idea that every individual has a "right" to a healthy and attractive natural environment.

(2) The decision-maker is provided with additional information. This information is especially relevant and useful when values are involved that are not readily quantified 80 that the decisions to be made are essentially value judgments.

(3) Greater accountability is fostered in political and administrative decision-makers. Decisions (and therefore responsibility) may tend to be forced higher in the policy decision hierarchy scrutiny through public participation. Scrutiny through public participation also helps ensure that required procedures are followed by decision-makers.

(4) Members of the public are given some assurance that all relevant issues have been considered as thoroughly as reason and good sense require. Therefore public confidence in the decision-maker or reviewer and his policies is enhanced.

There are various means of involving the public in an assessment process. The public hearing is a well-known device but not the only one. One writer has identified other devices as including perception and attitude surveys, written representations, on-the-spot community monitoring and "independent" advisory bodies. 5 It is apparent that flexibility of participatory procedures may be necessary to fulfill the diverse needs of various assessments and one method may not serve all purposes. It is, however, necessary that some form of public input should be a mandatory requirement and the mode of that input be tailored to differing circumstances. "Public participation is an alternative to legal actions for ensuring that public officials charged with the administration of the environmental impact assessment process follow the proper procedure in all cases."6

For this reason the requirement for public participation should be mandatory although the actual mode may vary in different situations to ensure that the most appropriate means is employed.

\section{B. When an Assessment is Required}

It is a relatively straightforward task to identify those kinds of projects which typically have potentially significant environmental effects and therefore require an Environmental Assessment document. Similarly there is no great difficulty in developing a categorization of kinds of undertakings which have no potentially significant impact and thus should be exempted from the environmental assessment requirement. However, between these extremes there is a large gray area comprised of projects which have significant impact in some circumstances and not in others. ${ }^{7}$

1 Environment Canada, Task Force on Environmental Impact Policy and Procedure, August, 1972.

3 Lucas, A.R., "Environment Impact Assessment: Legal Perspective", Proceedings of National Conference on Environmental Impact Assessment: Philosophy and Methods, Agassiz Centre for Water Studies, Manitoba, November, 1973, 46.

Id. at 43.

7 Green Paper, Supra, n. 2 at 10. 
As it is not possible to categorize the actions which will require an assessment, an element of discretion is necessary. It is always desirable that a discretionary element is limited as much as possible $e^{8}$ by at least delineating the areas where an assessment will always be required. It is suggested that such an area could be any project which will have obvious physical effects, e.g. a dam, a highway, a factory. Such projects will have what have been called primary effects, i.e. physical impacts. The more difficult decisions involve secondary effects which may not result from the specific project itself but be consequent upon it. Examples of this type may be a decision to require returnable bottles which may result in decrease in bottle manufacture and increase in tin cans. This latter type which produces secondary impacts notobviously connected with the actual action will often be connected with policies, legislation and actions rather than with physical projects or developments.

There is a need for some type of screening mechanism. It has been suggested that there are three possibilities: ${ }^{9}$

(a) the proponent

Under the National Environmental Policy Act in the United States the responsibility is upon the proponent of an action to decide whether or not the impact of a proposal will have significant environment impact. It has been noted that: 10

The experience to date with this approach indicates that public disagreement with the decisions of originating organizations has given rise to a large number of lengthy and expensive cases.

This illustrates the result of mixing the scientific and social issues. When a proponent decides whether the impact is significant he is making a value judgment. It is suggested that the proponent should identify theimpact and a wider body should evaluate the "significant" factor.

\section{(b) government agency}

A government agency could delineate projects through regulations or by review of each project. This shifts the decision factor from the proponent to the government agency. The agency must decide two things: what is the impact and is it significant. This ensures that questions of social choice arise in the government circle. These issues can be given a broader basis depending on the procedural requirements adopted by the department, i.e. whether other agencies and the public are involved or not.

\section{(c) an independent screening board}

As many projects and policies may emanate from government departments, it has been suggested that: ${ }^{11}$

It should be open to concerned citizens and groups to invoke a procedure that would require the Review Board to determine in public whether an environmental assessment document is required, when the exemption of a project from compliance is contemplated by either a project proponent or the screening body.

It is suggested that (b) and (c) are preferable to (a) as they both entail an element of objectivity and disinterest not possiblein (a). Nonetheless there is

\footnotetext{
* The problems associated with uncontrolled discretions are explored by Davis, K.G., Discretionary Justice: A Preliminary Study, Louisiana State University Press, 1969.

- Green Paper, Supra, n. 2 at 11.

"Id.

"Canadian Environmental Law Association, Principles of Environmental Impact Assessment, 17 (1973).
} 
still inherent in (b) and (c) the possibility that proposals will be presented in such fragmented form that no impact will be evident, e.g. a ten mile stretch of highway which in fact is part of a much bigger proposal. It is necessary therefore to have a procedure which will ensure that specific proposals are not only viewed for environmental consequences but also viewed within the broad framework of which they are a part. This problem brings into focus the need to review the policy proposals rather than merely specific actions. At the policy stage there are more alternatives open for consideration than when a policy has been determined and specific projects within that policy are implemented. If one considers the question of impact at the policy stage rather than at the more specific project stage the tool is being used to its full potential. One writer has suggested that "the entire subject of environmental impact assessment in advance of proposed projects is far less important in decision making than the public has been led to believe." 12 The important word he uses is "projects", for it is suggested that slightly different considerations are involved with projects than with proposals and policies. By the time a proposal or policy has reached the stage of implementation through a project, many of the alternatives have been foreclosed. It is important therefore to distinguish between these stages of decision making. On the one hand there is the broad policy and at this stage the proponent sifts through various means of implementing the policy; when a means of implementation has been selected this is the project stage; when this stage has been reached many alternatives have been discarded and the ambit for assessment is considerably narrowed to a choice of the least detrimental course or design. If assessment is invoked at the earlier planning stage, then the focus is not upon one particular project but several project alternatives capable of achieving a desired goal.

It must be realized that from the date of government adoption of an assessment process several years will elapse before its full potential can be utilized. This is because of the substantial lead time which elapses from policy proposal to commencement of project developmen $t^{13}$ which will result in many proposals being already underway to an extent where substantial alteration is foreclosed. In the early stages after a procedure is adopted it will be used in many cases where alternatives have already been foreclosed and the only issues which can be influenced will affect design modifications or alterations. There are many examples in the United States where assessments have become mandatory several years after planning had been initiated. ${ }^{14}$ The problems during the transitionary period have been substantial in the United States and indicate that there are many considerations which are more easily dealt with at the policy stage and become extremely difficult to assess once the project has been agreed upon..$^{15}$ The United States experience provides an excellent example of the need for varying procedures to deal with, firstly, broad policy questions at an early stage and, secondly, more specific procedures to assess individual projects once a project has been assessed as the most preferable of alternatives for action.

It has been suggested that the government should establish an indepen-

12 Peterson, Environmental Considerations in Northern Resource Development, (1973) Centre for Continuing Education, U.B.C. at 2.

13 It has been estimated that this time lapse could be at least ten years in some instances, see Kessler, "The Federal Highway Administration", Ditton and Goodale (Eds.), Environmental Impact Analysis: Philosophy and Methods, University of Wisconsin, 1972, 47.

1" This point is discussed by Lawyer, D.E., "The U.S. Army Corps of Engineers", Ditton and Goodale, Id. at 55.

is The problems encountered in the United States situation are fully discussed by Anderson, F.R., NEPA in the Courts: A Legal Analysis of the National Environmental Policy Act, John Hopkins Press, 1973, Chapter V. 
dent screening board with the power to demand assessments and public hearings where it deems appropriate. ${ }^{16}$

An independent screening board appears preferable to utilization of a government department which has a limited area of interest and jurisdiction and is subject to departmental pressures and bias where its own projects are involved. If the policy is to realize its full potential, then there should be provision for public input at this stage where the board decides that an assessment is not necessary. As this decision is a value judgment its efficacy should be scrutinized by the broadest spectrum of opinion. A decision to require assessment will enable public input at the review stage, but a decision to by-pass assessment will foreclose further input unless it is guaranteed at this juncture.

Possibly a two stage process may evolve where the initial assessment can cover a wider spectrum of issues before a policy is committed to the project stage.

Whatever procedure is adopted, the need for a public voice in the determination of whether a proposal is one of such significance that an assessment is necessary is very apparent.

\section{The Preparer and the Contents}

It has been suggested that there are five options available concerning the question of who should be responsible for preparing the assessment. ${ }^{17}$

The first alternative proposed in the "Green Paper" discusses the possibility of utilizing the services of independent consultants.

The advantages inherent in the use of consultants are several. Firstly, the consultant is not committed to proceeding with a particular project and therefore should have no particular bias in favour of proceeding which would unduly slant his perspective. Secondly, the employment of independent experts may provide an outside input which could produce innovative approaches. Thirdly, individual proponents and government agencies would not be faced with the enormous overheads connected with expanding staffs necessary to deal with an interdisciplinary assessment.

The disadvantages tend to counterbalance the advantages. Firstly, it could be that consultants will wish to reflect the bias of their employer for fear of losing the contract. Secondly, the existence of numerous consulting firms would result in implementation of as many methodologies. Thirdly, the employment of outside consultants would isolate the environmental considerations from the other aspects of the planning process.

It would seem likely that as applied environmental science becomes more established consultants will be used to some degree no matter which of the alternatives is chosen. It will therefore be assumed that there are really only four alternatives and whichever of these is chosen the likelihood of someindependent consultant input in the assessment process will be taken for granted. The degree of input will depend on both the nature of the proposal and the resources of the preparer to research it.

\section{(a) Department of the Environment}

If the Department prepared the assessments there would be consistency in methodology and the expertise would tend to be centralized within one government department, preventing duplication of skills in other

1i Environment Protection Board, Proceedings: Workshop on the Philosophy of Environmental Impact Assess. ment in Canada, Winnipeg, October, 1973, 51.

17 Green Paper, Supra, n. 2 at $18 \mathrm{ff}$. 
departments. This option still has the disadvantage of removing the assessment requirement from the other planning stages so that the environmental considerations remain outside the contemplation of the proponent.

\section{(b) A New Agency}

It has been suggested that a new agency could vitiate the tendency of the Department of the Environment to be biased against any development projects because of its conflicting role in relation to them. The establishment of a new agency for this purpose would further fragment the responsibility of government for environmental protection and there may be conflicts with existing duplication of expert personnel.

\section{(c) Individual Departments}

This option contemplates that any department which required an approval for a project or project stage would prepare an assessment before granting the necessary approval. This option places a heavy demand on existing departments and requires that they widen their perspectives if they are to produce a satisfactory integrated approach. Most statutes do not presently enable departments to consider all that would be required of them. It would seem therefore that statutory amendment would be essential. ${ }^{18}$ Often permits or approvals are granted late in the planning process and this would not enable the early consideration contemplated to be undertaken. ${ }^{19}$ This option would also tend to fragment any assessment and could resultin conflicting attitudes in different departments. Some provision for coordination of departmental permits and approvals would seem necessary.

\section{(d) Originator or Proponent}

Where the proponent is required to prepare the assessment the most significant benefit would seem to be that it forces him to direct his attention to environmental matters and as he is in the best position to influence the decision-making, a newly acquired environmental awareness could be very significant. In the United States the federal agency is responsible for the assessment and it has been found that "where agencies have hired new personnel with new specialties, their presence has been like a fresh breeze down most bureaucratic corridors."20 This is an important positive element, for not only does it promote a development of environmental expertise within an agency, but it tends to create a new institutional viewpoint which is necessarily more sympathetic to environmental concerns. The broadened agency focus will be an inevitable result of utilizing an interdisciplinary approach.

One difficulty of requiring a proponent to prepare the assessment is that individual departments are set up with certain objectives. It would seem an almost impossible requirement to ask that these agencies question the very premise on which they exist, e.g. it would seem natural for Hydro to assume that it needed to meet the demand for power. Whether one should curb the demand is probably outside the ability of those involved to adjudge. The careful development of procedures for the guidance of agencies in the preparation of their assessments could probably overcome this difficulty by insisting upon input of those outside the agency on this type of issue.

The other difficulty with this option is whether it should apply alike to

18 Parisien and Reuben, Supra, n. 1 discuss this issue.

19 This is illustrated by the Utah Mines controversy which is analysed by Lucas, and Moore, The Utah Con. troversy: a Case Study in Public Participation in Pollution Control, (1973) 13 Natural Resources Journal 36.

20 Lake, W.T., "The National Environmental Policy Act" in Environment Protection Board: Proceedings, Supna, n. 16 at 22 . 
public and private sectors. One writer has suggested that the procedures and methodology that are to be developed for preparing environmental impact assessments for public undertakings may be inappropriate to the private sector. ${ }^{21}$

Whereas it may be considered beneficial to require government departments to increase their staffs to provide an interdisciplinary team to consider the issues, it may be impractical to expect the same of small businesses accustomed to hiring independent consultants to determine questions of economics and technology.

It may also be beneficial to vary the role of government departments depending on whether they are the sole proponents or regulators; a different format may be appropriate where several departments are involved.

There would seem to be no definitive answer to the question of who should prepare the assessment which would be appropriate in every case. As noted earlier different procedures may be necessary depending on whether the proposal emanates from the public or private sector. It would therefore seem desirable to formalize procedures with sufficient flexibility to ensure that the person or body most able in the circumstances carries the responsibility for the assessment.

The data which should be contained in an assessment document has been the subject of much literature. ${ }^{22}$ This is an important issue because it would seem clear that there is a need for detailed information to aid whoever prepares the assessment. The initial question of what should be evaluated in the assessment requires some decision to be made on what is important or significant. The answer to this may vary depending on the preception of the person asking the question. The need for detailed information to assist the person preparing the study is obvious. The development of such information will depend on which body is given the task of deciding when an assessment is required. There may be circumstances when various departments wish to develop the information and relate it to specific projects.

In preparing the assessment it must be decided whether the assessment should be directed to the scientific community, a reviewing body or the general public, as each of these groups has an interest in the data of the assessment. The most useful assessment will provide the scientific reports and calculations on which the data is based and identify the assumptions made and the personnel responsible. Conclusions will be in a summary form understandable by the layman so that he can evaluate the trade-offs to be made between the proposal and its alternatives.

\section{The Nature of the Review Process}

It is necessary first to establish the purpose of the review process. A distinction must be drawn between a review process which establishes whether the assessment is adequate, i.e. whether procedural guidelines have been adhered to, and a review process which evaluates whether the net benefits of any project outweigh the net costs and whether the environmental effects reflect the least harmful trade-offs possible.

The review process can serve both functions or one only. It can provide a means for evaluation of the arguments or a weighing of values and it can

" Paavila, H.D., "Environmental Impact Assessment: Industrial Perspective", Supra, n. 5 at 56.

22 Literature includes: Leopold et al., A Procedure for Evaluating Environmental Impact, 1971, Geological Survey Circular 645; Sorensen, Proposed Guidelines for the Preparation and Evaluation of Environmental Im. pact Statements Under the California Environmental Quality Act of 1970, Sec. for Resources, Sacramento, 1971; Environmental Control Ministry N.S.W., Guidelines for Application of Environmental Impact Policy in New South Wales, 1973. 
test adherence to procedural requirements. The latter function presupposes published guidelines; it is a checking process to ensure that the guidelines have been adhered to, that the fullest inventory has been made and the most thorough consideration of effects has been explored.

If the procedure adopted for preparing the assessment has given every opportunity for the airing of conflicting views and for the full consideration of all consequences of a proposal it would seem necessary that the review stage should be concerned only with the question of whether the procedural requirements have been met.

Thus the review process would give an opportunity to any interested person to allege that the assessment was not adequate because it had omitted some step which was required. This challenge may arise before an independent board or a court.

There would appear to be opportunity for review by various departments also because it is difficult to imagine a project which could proceed without some departmental permit or approval. As mentioned previously, the permit approval stage is at present late in the planning stage. Consideration could be given to changing this timing by statute and also to amending statutory powers to require departments to review environmental matters either on their own or in conjunction with other departments as a condition precedent to issuing permits and approvals.

The purpose of the assessment process is to improve decision making. Thus the process should ensure that decisions cannot be made without due consideration of environmental matters.

In the United States the ultimate decision of whether to proceed or not is left with the proponent of the action. There is no legal requirement to force him to weigh his decision against the facts of the assessment. Any coercion is external to him and may materialize in the form of permit refusals; if he can obtain his permits then although more desirable alternatives may have been demonstrated he is not required to act on them. The only recourse is through the courts where his actions may be delayed or altered, not because he failed to act on his evaluation but because his evaluation was not adequate. The goal of the United States legislation is to improve the decision process by requiring assessment but it does not go the further step of seeking a method of dictating the correct decision.

It is suggested that this is the preferable approach. The previous discussion illustrates that there are many procedures which could be utilized and it may be necessary to develop different procedures for different circumstances. Whatever procedures are adopted they should, firstly, provide the opportunity to the public to partake in each of the decision stages. Secondly, they should require the publication of regulations or guidelines which must be followed; and thirdly, they should provide the means whereby any interested person can challenge an assessment on the ground that the procedure has not been followed.

The United States experience, which will be discussed in Section IV of this article, bears witness to the fact that much of the success of any assessment procedure is largely dependent upon a means to enforce compliance. It is not sufficient merely to announce a procedure without providing any enforcement mechanism as the next section which analyses the Canadian federal proposal will reveal.

In adopting a procedure it is therefore important to direct attention to the means which can be utilized to enforce compliance with the procedure. Much 
attention has been given to the enforcement mechanisms of the courts in the United States.

The Parliamentary system rests on principles different in nature from the Congressional system. It is likely therefore that solutions to the problems of enforcement found successful in the United States may not necessarily be appropriate to the Parliamentary system. These issues are the subject of Section V of this article.

\section{THE CANADIAN PROPOSAL}

\section{A. Background}

The federal government has not been unaware of the potential of an environmental impact assessment procedure. Impact assessment was one of the six goals stated as departmental objectives when Environment Canada was established in $1971^{23}$ and in March 1972 a cross mission task force was established within the Department of the Environment to report to the management committee on environmental impact assessment with a view to placing a proposal before the Federal Cabinet to launch an interim phase. $^{24}$

During its five month existence the Task Force spent one month as an information gathering period during which discussions were held with environmental authorities in the United Kingdom, Holland, the U.S.A., the Provinces, and in other federal government departments. In the U.S.A. the Task Force consulted with the Council on Environmental Quality, the Environment Protection Agency, Committee staffs of the House of Representatives and The Senate, Library of Congress Environmental Policy Division, legal counsel for citizens' groups, the Army Corps of Engineers, the Bureau of Reclamation and others. Policy formulation was initiated at a two day workshop in May. This phase continued through June in liaison with two consultants. Procedure development took place from June to August in co-ordination with consultants on the technology of environmental impact assessment and in procedure simulation exercises held atdepartment headquarters. 25

The final report contained a specific proposal for adopting a procedure. The basic features of the proposal were that the proponent would be responsible for preparation of the environmental impact assessment on the basis of guidelines provided by a newly established and independent Environment Review Board. The Review Board would administer the procedure and make recommendations, but not render decisions on proposed actions. The Board's role would also be to ensure that statements were made public and that the public had the opportunity to participate. The need for the Board to be independent, disinterested and flexible was stressed. It was envisaged that the procedure would be a two stage process: a preliminary screening, one which could indicate that there would be no significant impact, and a more detailed procedure for actions where it appeared a significant impact may result.

The Task Force proposal is very attractive. It separates the three decision stages. The Independent Review Board decides the significance of the action and the adequacy of the assessment but it leaves to the propo-

2.4 Environment Canada: Its Organization and Objectives, Information Canada, Ottawa, 1971.

24 Management Committee, Environment Canada, memorandum, February 18, 1972.

25 Task Force on Environmental Impact Policy and Procedure, Final Report, Environment Canada, August 30 , 1972. 
nent the final decision of whether to proceed or not. It deals separately with technical matters and value judgments by broadening the decision base, by encouraging public involvement, by publishing the decision not to prepare statements and by including the public in the review process. As a criterion for environmental impact assessment the Task Force proposal represents good policy because it reflects the considerations necessary to achieve the policy objective of improving decision making by making environmental concerns an integral part of the decision process.

When the Minister for Environment announced the introduction of a Federal Environment Assessment and Review Process in the House of Commons on 14 March $1974^{26}$ he departed quite significantly from the Task Force proposal.

The Minister announced that beginning April 1, 1974 federal government projects will be screened to ensure that they do the least possible damage to our environment. Federal departments, Crown agencies and private companies with government contracts, grants and loans will have to prepare environmental impact statements. The statements will be screened by a panel of experts within the department who will make recommendations to the Minister. The proponent will be responsible for the preparation of the statement following guidelines to be issued by the department. The written assessments of the expert panel will be published. In cases of broad public interest the Minister may appoint a review board from outside the public service to hold public hearings and publish recommendations. This procedure has several weaknesses. First, it would appear that the criteria of what amounts to significant impact on the environment will be decided within the department and the perceptions of the department on the impact of a project will be published. The facts will be presented to the public with the values already decided. Second, public participation will be limited to projects which evoke a broad public interest. It is difficult to visualize how public interest will be assessed when the public is not given any opportunity to know which projects are planned. Third, the proposal deals only with projects. It completely omits other actions which the Task Force identified as policies, programmes, legislative proposals and operational practices. The proposal does not heed the advice of the Task Force that "this project by project approach is not adequate to solve the problem of environmental impact." 27 The proposal does not face the reality that:28

Information is likely to have its greatest impact early in the planning process while the need for an airport, highway, dam, power plant or pipeline is still being discussed, and before a site is selected. Once the issue has been placed in context, the decision maker will follow routine patterns and listen to regular sources.

Fourth, an independent review board will be used only in cases of broad public interest. The likelihood of public interest developing is thwarted by a lack of information. In nearly all cases the entire procedure will be carried out in the secrecy of departmental administration where factual data will be given values without the benefit of a disinterested body influencing the process. In fact the Minister stated that the process will be

${ }^{26}$ (1974) 118 H.C. Deb. No. 12, 499-500.

${ }^{27}$ Task Force Report, Supra, n. 25 at 5.

28 Ingram, Information Channels and Environmental Decision Making, (1973) 12 Natural Resources Journal 150 at 157. 
put into effect "in close consultation with the provinces and with industry";29 this is not an optimum result.

\section{B. Environmental Policy Within the Context of Canadian Federal Politics}

The broad goals of the federal government in relation to natural resources and the environment have been reported as, on the one hand, to ensure that all Canadians have access to a style of life befitting a nation rich in natural resources and, on the other hand, to safeguard these natural resources for future use by the present generation and the generations to follow. To this end Environment Canada ${ }^{30}$ has been established to help ensure the protection, preservation and enhancement of Canada's environment while encouraging efficient use of its natural resources. ${ }^{31}$

Environment Canada has a dual role of developing resources and of preserving environmental quality. Inherent in these roles is the conflict of growth versus conservation which beleaguers most environmental policies. ${ }^{32}$ The likelihood of resolving these conflicts by head-on confrontation is unlikely without guaranteed mass support for one over the other. Instead, one department with dual conflicting goals attempts to serve both objectives to a degree.

The establishment of Environment Canada does at least recognize the need for a holistic approach in dealing with environmental questions and therefore has potential if objectives and priorities are more specifically stated.

The environmental impact assessment procedure introduced into the Commons in March 1974 did not mark a new policy but a change in emphasis of existing policy. When Environment Canada was established one of the six goals of the department was to assess and control the environmental impact of major development and to do this by an improved mechanism for consultation and co-ordination of government effort. ${ }^{33}$ In answer to a question concerning Federal government intentions for environmental legislation Mr. Davis indicated that his government was considering legislation along the lines of the National Environmental Policy Act in the United States. He said: ${ }^{34}$

We are developing legislation at the federal level but this would apply only to projects which are international or inter-provincial. I would say that two-thirds of the decisions would still be made at the provincial level, so you would have to look to provincial or municipal law to give you that entree into the decision-making process at these levels.

The jurisdictional question offers one explanation for the eventual adoption of so timid a proposal. As one of the major concerns of Cabinet is the unity of the country, a policy in an area of overlapping jurisdiction will cause the federal government to move cautiously for fear of alienating one or more of the provinces, especially if those provinces are

\footnotetext{
2y The need for close liaison between government and industry was also stressed in Environment Canada: Its Organization and Objectives, Supra, n. 23,

${ }^{30}$ Government Organization Act 1970, R.S.C. 170, 2nd Supplement, c. 14.

31 Canada Yearbook, 516 (1972).

32 Environment Canada: Its Organization and Objectives, Supra, n. 23, stresses that "in the Department of the Environment, fisheries responsibilities command continuing priority."

s.) Id.

34 Efford and Smith, (Eds.) Energy and the Environment, (1971), H. R. MacMillan Lectures, Institute of Resource Ecology, U.B.C. at 202-3.
} 
large or influential. ${ }^{35}$ Freed from provincial jurisdictional restraints it would appear that the Federal government would act more assertively. The Territorial Land Regulations are evidence of this. ${ }^{36}$

Another problem would appear to be concern for departmental boundaries within the Parliamentary system as the following exchange between Mr. Davis and Mr. Fraser, taken from the Minutes of a Fisheries and Forestry Committee in 1973, illustrates: ${ }^{37}$

\begin{abstract}
Mr. Fraser: Has there been any serious consideration by the government to secure this procedure by enacting legislation which would require the Department of the Environment to peruse and approve of any project done by another department from an environmental point of view before it goes ahead?

Mr. Davies: I do not think legislation along those lines would be considered very rational, at least in a parliamentary type of government. You are talking about relationships between private individuals or other governments with the federal government. You are talking about relationships between agencies and departments within a single government, and this typically is covered in all parliamentary systems by the administrative arrangements and not by a legal requirement. Surely the government can sort out its own differences internally without requiring a law of Parliament to require it to do 80 .
\end{abstract}

The Minister's remarks in this exchange bear little resemblance to the words he uttered in response to a similar question two years earlier.

Apart from jurisdictional concerns it seems clear that the government will be more likely to respond to policies with short-term rather than long-term benefits. A policy which promises long-term benefits but shortterm costs will be politically less attractive. The Task Force identified certain short-term costs involved in its proposal which would entail short-run adjustments within the economy to accommodate added construction and operational costs and a reallocation of resources from one sector to another. The benefits from adoption of the proposal were all identified as long-term. ${ }^{38}$ Government does not by itself respond to longterm "preferred futures".

The government will only respond to long-term demands if the present pressure is strong. Its presence can bring action which results in future benefits. Demands may emanate from three sources.

First, the department may press for change. Environment Canada did this when the Task Force was appointed. However, the Cabinet system leaves little room for individual departmental policies which are at odds with the consensus of Cabinet. If the demand is felt therefore only in one department and lacks the consensus of other Ministries the departmental initiative will be diluted until it reflects the lowest denominator of accord. The system therefore requires pressure from more than one department; it requires a conviction amongst a majority of Ministers before a change will result. It seems apparent that one Minister could persuade his fellows of the need for such a change. It also appears that the influence of a particular department will be relevant in how persuasive a measure appears, influence being determined by budgetary allotment and portfolio functionability. Environment Canada is not one of the functional portfolios in terms of budget; it ranks eleventh behind

25 The low profile taken by the Federal government in the dispute over the James Bay development illustrates this.

36 These regulations apply under the Territorial Lands Act, R.S.C. 1970, c. T-6, which applies in the Yukon and Northwest Territories. Under the regulations an applicant for a permit must make an environmental impact assessment of his proposed action before a permit will be issued.

37 Minutes of the Fisheries and Forestry Committee, Issue No. 8, April 10, $19738: 9 ; 8: 10$.

38 Task Force Report, Supra, n. 25. 
departments whose objects are expansion and exploitation of natural resources. ${ }^{39}$

As government is concerned with the immediate impact of policies, and in so far as environmental implications are more remote, then any influences from pressure groups would tend to be oriented towards development rather than conservation. ${ }^{40}$

\section{The Likely Impact of the Review Procedure}

There seems little reason to believe that the review procedure announced by the Minister will result in activity very different from that experienced in the past. One aim of the Environment Protection Service has always been to take action in preventing or combatting environmental problems for which the department has responsibility; this responsibility includes control of activities having an ecological impact.41 The Federal proposal does not expand this concept. First, it deals specifically with projects. It has been previously noted that the lead time between proposal and project can be up to ten years and that by the time a project has been crystallized in the minds of proponents many alternatives have been foreclosed. Second, the procedure is designed to ensure that the least possible damage will occur. This is the philosophy so vehemently criticized by Peterson. ${ }^{42}$ In such circumstances the procedure is utilized merely to limit environmental harm by choice of design and use of technology. It denigrates the process to dealing with technological impacts and avoids the more complex and urgent problem posed by social choices. Third, the Environment Assessment Panel established to determine the threshold question of when an assessment will be required is not an independent body but one within the department. ${ }^{43}$ It will therefore be subject to the same political pressures that are at work throughout the department to balance out conflicting interests. Its recommendations are made to the Minister who in turn will be subject to Cabinet accommodations. The result will, in many cases, be circuitous as many federal projects on which the panel will be required to deliberate will already have been approved by the Cabinet and the obvious bias in favour of proceeding will have nurtured before the Panel sees an impact assessment.

Fourth, the opportunity for public involvement in the process appears minimal. It is not until "broad public interest" has been displayed that there will be likelihood of an independent Review Panel or any public hearings. It would seem unlikely that public interest will germinate unless the public is informed. The conundrum posed by this aspect of the procedure is not difficult to solve; in most cases there will be no participation.

Fifth, the value judgments which the process involves will all be made within the department without the attempt to open the decision framework to scrutiny. As there are no indicators of public attitudes to actions without public consultation the only yardstick by which

${ }^{39}$ Neale Adams, Saving Our Environment Slowly, Vancouver Sun, Oct. 20, 1973 at 6.

40 Ingram, Supra, n. 28 at 159. Presthug has also noted that the majority of Liberal campaign funds come from industrial interests. Presthus, R., Interest Groups and the Canadian Parliament: Activities, Interaction, Legitimacy and Influence, (1971) 4 Can. J. of Political Science 444 at 452.

"S Supra, n. 23.

42 Peterson, Supra, n. 12.

13 On May 25, 1974, the Minister announced the appointment of Panel Chairman Dr. R. Reed Logie, the former Assistant Deputy Minister of Fisheries and, until his new appointment, Secretary of the Environmental Advisory Council. 
judgments can be made is the perception of particular departments which must, whether consciously or not, be biased in favour of the project.

At worst the proposal is not new at all and merely formalizes what one hoped was already happening within the department. At best it is a first very faltering step toward a later more comprehensive proposal which will reflect clearer objectives and provide the necessary institutional arrangements to ensure that the procedures do become part of government decision making processes. Experience in the United States has suggested that departments change processes slowly and unwilling. ly. Even the legislation enacted there to formalize the process met with resistence in agencies and many agencies sought exemption from its provisions. There is no reason to believe that Canadian departments will act differently from their U.S. counterparts. It seems essential that, if impact assessment is to become part of the decision-making processes, legislation will be required to assure its adoption. The model law has been provided by the United States. The impact of the United States statute and the difficulties inherent in attempting to transplant it into the parliamentary system form the next subject for discussion.

\section{THE NATIONAL ENVIRONMENTAL POLICY ACT}

\section{A. The Background}

The National Environmental Policy Act was signed into law on January 1, 1970.44 This Act was the end result of Congressional discussions which spanned more than a decade. ${ }^{45}$ As has been noted earlier, democracies tend to respond to problems rather than to seek preferred futures. The history of N.E.P.A. is no exception to this philosophy.

The first attempts to establish a national goal for environmental policy can be traced to the Resources and Conservation Act 1960 which was introduced into the 86th Congress by Senator James Murray. ${ }^{46}$ The purpose of this bill was to declare a national policy. This bill was never adopted and environmental measures were relegated to the administrative processes.

The questions concerning environmental quality gained momentum throughout the country in the sixties and by 1964 had become a major theme in Johnson's presidential campaign. Although the environment played only a minor part in Nixon's campaign after his election he appointed a Task Force under Russell Train to examine the issues involved in environmental quality questions. The Task Force was forceful in its suggestion that the new administration should give the issue high priority. The Task Force recommended appointment of a special Presidential assistant for environmental affairs who would also serve as executive secretary of a new President's Council on the Environment.

The President did not heed the advice of the Task Force concerning a special assistant but preferred a Cabinet level interagency coordinating committee established by executive order. Meanwhile Senator Jackson, who favoured establishment of a permanent body in the Executive Office of the President, had introduced a Bill into Congress on February 17,

44 42. U.S.C. 4321.

is The full legislative history is set forth in Yarrington, H.J., The National Environmental Policy Act, (1974) 4 Environment Reporter Monograph No. 17, Jan. 4, No. 36. The earlier bills are discussed in Cooley, and Wandesfordesmith, (Eds.) Congress and the Environment, University of Washington Press, Washington 1970.

46 S. 2549, 1959, 86th Congress. 
which proposed such a Council. ${ }^{47}$ In April the Senate conducted its hearing on the Bill and six weeks later an amendment was added which declared a national policy. Two later amendments altered the right to a healthful environment to the phrase "each person should enjoy a healthful environment" and the provision "for a finding" in relation to environmental impact to a "detailed statement" of impact. The Bill was passed unanimously and without debate by the Senate on July 10, 1969. Before submitting its Bill to Senate-House conference committee several changes were made including the amendment believed to be the forebearer to s.102. The conference reached agreement on December 17, both Houses agreed to the report and a week later it became law.

After so many years of discussion it may seem that the Act became law without much opposition. There are two events of political significance which occurred during 1969 which may well account for the changing attitude. In January of 1969 a break in an underwater oil well in the Santa Barbara Channel covered a substantial length of ocean frontage with crude oil and caused extensive destruction to bird and marine life and the beaches. Secondly, in May, 1969 the Department of Defence announced its intention to dump 27,000 tons of surplus deadly nerve gas and other chemical weapons in the Atlantic. Both these events brought heated protests from the people and the press. ${ }^{48}$

The American public was becoming sensitized to environmental quality issues and unperceptive government agencies doing business as usual suddenly found themselves in deep trouble over matters that formerly could have been considered as merely technical, if not routine operations. ${ }^{49}$

These events were sufficient to set the political stage for Congress to provide an answer; the result was the National Environmental Policy Act. ${ }^{50}$

\section{B. NEPA: Its Provisions}

In passing NEPA the Congress had several purposes which can be elucidated from an examination of the declaration of purposes and the two separate titles.

\section{Section 2 states the purpose of the Act as follows:51}

To declare a national policy which will encourage productive and enjoyable harmony between man and his environment; to promote efforts which will prevent or eliminate damage to the environment and biosphere and stimulate the health and welfare of man; to enrich the understanding of the ecological systems and natural resources important to the Nation; and to establish a Council on Environmental Quality.

Title I, consisting of five sections, amplifies the policy declaration and sets forth procedures for effecting it. The policy declaration recognizes the impact of man upon his environment and the growing awareness of the deterioration of the environment as a result of this impact and declares: 52

... the continuing policy of the Federal Government, in cooperation with State and local governments, and other concerned public and private organizations to use all practicable means and measures, including financial and technical assistance in a manner calculated to foster and promote the general welfare, to create and maintain conditions

\footnotetext{
17 S. 1075 introduced Fed. 18, 1969.

4s The account is related in Caldwell, Environment: A Challenge for Modern Society, 211, (1970).

is Id.

so Hereafter referred to as NEPA.

3142 U.S.C. 4321.

3242 U.S.C. 4331.
} 
under which man and nature can exist in productive harmony, and fulfill the social, economic and other requirements of present and future generations of Americans.

In order to carry forth this policy the Act recognizes that the Federal government has a continuing responsibility to use all practical means consistent with other essential considerations of national policy to strive toward the following goals: ${ }^{53}$

(1) to fulfill the responsibilities of each generation as trustee of the environment for future generations;

(2) to assure for all Americans safe, healthful, productive and aesthetically and culturally pleasing surroundings;

(3) to attain the widest possible range of beneficial uses of the environment without degradation, risk to health or safety or other undesirable and unintended consequences;

(4) to preserve important historic cultural and natural aspects of our national heritage, and maintain wherever possible an environment which supports diversity and variety of individual choice;

(5) to achieve a balance between population and resource use which will permit high standards of living and a wide sharing of life's amenities;

(6) to enhance the quality of renewable resources and approach the maximum attainable recycling of depletable resources.

Having set forth national goals and priorities the Congress then recognized the right of each person to enjoy a healthful environment.

The next section sets forth the procedures whereby federal agencies incorporate the policies and goals into their activities and directs that existing laws, regulations and policy be interpreted and administered to "the fullest extent possible" in accordance with the policies set forth in the Act. All agencies are required to: ${ }^{54}$

1. utilize a systematic interdisciplinary approach;

2. identify and develop methods and procedures to assure that consideration is given to unquantified environmental amenities along with traditional concerns of technology and economics;

3. to prepare environmental impact statements;

4. to study, develop and describe appropriate alternatives where any unresolved conflicts concerning resource use arise;

5. be mindful of the international nature of the environmental questions;

6. make available advice and information on the quality of the environment;

7. initiate and utilize ecological information;

8. assist the Council on Environmental Quality.

Every agency is required to review its statutory authority, administrative regulations, policies, and procedures to identify any deficiencies or inconsistencies which would prohibit full compliance with the goals of the statute and propose to the President any measures which may be necessary to bring them in line with NEPA goals. ${ }^{55}$ Provision is also made to ensure the NEPA will only expand and not limit environmental mandates of agencies.

Title II of the Act deals with the Council on Environmental Quality. In seven sections it provides for the President to submit an annual environmental quality report, ${ }^{56}$ establishes the Council of three, appointed by the President, ${ }^{57}$ gives the Council authority to appoint staff, ${ }^{58}$ and sets forth the duties of the Council as follows: ${ }^{59}$

\footnotetext{
s. Id.

s4 42 U.S.C. 4332.

s5 42 U.S.C. 4333.

s6 42 U.S.C. 4341.

5742 U.S.C. 4342.

sก 42 U.S.C. 4343.

s9 42 U.S.C. 4344.
} 
1. to assist and advise the President in the preparation of the report;

2. to gather timely and authoritative information;

3. to review and appraise various programs in the light of the policy;

4. to develop and recommend to the President national policies to further the goals;

5. to conduct investigations and studies;

6. to analyse changes and trends in the natural environment;

7. to make an annual report to the President;

8. to make reports as may be requested by the President.

The goals which Congress had intended by the enactment of NEPA are, as the summary of its provisions reveals, very broadly stated. The task of translating the goals into agency procedures commenced with Executive Order $11514^{60}$ which, again in general terms, required the agencies to implement NEPA's goals; to this end the Council on Environmental Quality was to issue guidelines to federal agencies for the preparation of impact statements. ${ }^{61}$ Interim guidelines were issued on 11th May 1970,62 and since then three additional sets have been issued.63

The achievements of NEPA and the Council on Environmental Quality ${ }^{64}$ in giving effect to the broad goals spelt out by Congress cannot be seen from the language of the Act but rather must be seen in the context of the system of government in which they were enacted. In the four years since its enactment "the flesh that now clothes the bare bones language of the statute has been added by the judiciary."65 In an understanding of the effects of NEPA it is important to look to the interpretations which have been built up in over 400 cases litigated since the enactment of NEPA. The large number of cases makes it impossible to analyse each achievement but for the purposes of this paper all that is attempted is some insight into trends which have been implanted in agency procedures by the active role of the courts.

The public have been the principal plaintiffs under the legislation and their role in the achievements also is worthy of attention.

The CEQ through its guidelines and role as overseer has also played a key role and not least the agencies of the federal government to whom the Act is directed.

\section{The Role of the Judiciary}

The active part taken by the judiciary in the development of NEPA was not a foregone conclusion at the beginning. While it is clear that the courts had jurisdiction to ensure that actions met strict procedural requirements of the Act, the courts could have stopped short of the active role which they have taken. However in the first decided case the court took the view that "it is hard to imagine a stronger mandate to the courts" 66 and this attitude has prevailed in the vast majority of proceedings under the Act.

The willingness of the courts to strictly oversee agency action under

\footnotetext{
60 Executive Order 11514 (March 5, 1970) 35 F.R. 4247 (March 7, 1970) Environment Reporter-Federal Laws
71:0121.

s1 Id. \&. 3(h).

62 CEQ interim guidelines May 11, 1970, 35 FR. 7390-7393 May 12, 1970.

63 CEQ guidelines, April 23, 1971, 36 FR. 7724-7729 April 23, 1971, CEQ guidelines May 16, 1972 issued as recommendations only and not published in the Federal Register. CEQ guidelines August 1, 1973, 38 FR.
20550-20562-August 1, 1973. Environment Reporter-Federal Laws 71:0301.

6s Hereafter referred to as CEQ.

6s Yarrington, Supre, n. 45 at 10.

s6 Texas Comm. on Natural Resources v. United States 2 ELR 20574 at 20575.
} 
the statute has been attributed to several circumstances and perhaps the strongest being that: ${ }^{67}$

NEPA has entered the lists at just the time the courts are generally tightening their review of agency decision making, and ... NEPA's reform-minded provisions contribute to the courts' efforts in the same way that stricter judicial review does.

Judicial review has centered upon the action forcing procedure set forth by $8.102(2)(c)$ which is as follows: 68

... all agencies of the federal government shall . . . include in every recommendations, or report on proposals for legislation and other major federal actions significantly affecting the quality of the human environment, a detailed statement by the responsible official on-

(i) the environmental impact of the proposed action;

(ii) any adverse environmental effects which cannot be avoided should the proposal be implemented;

(iii) alternatives to the proposed action;

(iv) the relationship between local short-term uses of man's environment and the maintenance and enhancement of long term productivity; and

(v) any irreversible and irretrievable commitments of resources which would be involved in the proposed action should it be implemented.

Nearly every clause of this section has been discussed by the courts during litigation under the Act.

The courts have dealt with the question of who should prepare the statement. It may seem clear from the section but controversy has arisen where more than one agency has been involved and where the responsible official has attempted to delegate the task especially in licencing and permit procedures. The CEQ guidelines have dealt with the former ${ }^{69}$ and the courts have defined more clearly the latter. The courts have distinguished between delegation of the task of preliminary assessment and delegation of the final assessment. Although some conflict exists between the decided cases the courts have made clear that the responsibility for the statement rests with the responsible federal official and is not left to an applicant who will tend toward preparation of a selfserving statement. ${ }^{70}$

The question of what actions will require the preparation of an impact statement has been broadly considered under the words "any major action significantly affecting the quality of the environment." Whether these criteria involves one test or two is moot. However it is clear that: ${ }^{71}$

... [1]t is safe to predict that where the Federal government is involved in a project in any way, no matter how slight, its involvement in the project will more than likely be considered "federal" action within the meaning of NEPA.

The same broad interpretations have been applied to the words "major" and "significant" so that a low threshold has been set to include most actions within the Act. ${ }^{72}$

The discretionary question of when an action comes within the terms

97 Anderson, Supre, n. 15.

on 42 U.S.C. 4332.

69 CEQ guidelines April 23, 1971, 8. 5b.

70 The state of law at present has some ambiguity. In some cases a degree of delegation, short of abdication of responsibility was permitted. The issues are discussed by Yarrington, Supra, n. 45 at 17.20, and Anderson, Supra, n. 15 at $186-196$.

7t Yarrington, Supra, n. 45 at 22.

72 There a fow cases which consider actions to be minor but Julis v. Cedar Rapids 3 ELR 20033 (N.D. Ia. 1972) involving city street repairs and Virginians for Dulles v. Volpe 3 ELR 20360 (Ed Va. 1972) involving landing facilities for larger aircraft at an existing airport are illustrative. 
of the Act has raised the problem of whether the courts should adopt a position requiring de novo review of the threshold issue or whether the test should be restricted to review to determine whether the agency has acted arbitrarily and capriciously.

The real significance of the dispute over standards of review is that if courts must rely on agency determinations, the agencies themselves can decide when to prepare statements. The very agents of a government whose environmental errors led to the adoption of NEPA would be able to set the threshold below which the Act would not apply. ${ }^{73}$

The adequacy of the statement, which is required to be a detailed one, has been a constant topic of litigation and judicial interpretation of the section has been instrumental in defining the standards which will be required. During the first year of NEPA the courts appeared satisfied with substantial compliance with the section and based the test of adequacy on bona fide criteria.74 This test was soon amended to one of strict compliance. Drawing strength from the words 'to the fullest extent possible' it was made clear that: ${ }^{75}$

... [T] not make NEPA's procedural requirements somehow 'discretionary.' Congress did not intend the Act to be such a paper tiger. Indeed the requirement ... sets a high standard for the agencies a standard which must be rigorously enforced by the reviewing courts.

All agencies have been required by the courts to comply with NEPA. The arguments of some agencies that their environmental protection policies are not within the mandate have not been accepted. In order to exempt EPA water quality decisions from the requirement of s.102(2)(c), statutory ame.1dment was necessary. ${ }^{76}$

Albeit brief, this outline of trends in judicial interpretation of NEPA indicates that the courts in the vast majority of cases have taken the words of the statute to indicate that the agencies' mandates have been widened to enable them to consider environmental matters previously disregarded as not within their scope and have taken the spirit of the statute to make inroads into agency procedures to ensure that the Act finds meaning.

\section{The Role of the Citizen}

NEPA provides that prior to making any detailed statement under s.102(2)(c) copies and comments thereon shall be made available to the President, CEQ, and the public as provided by Section 552 of Title 5 of the United States Code. ${ }^{77}$ The Act therefore makes it clear that the public is to be a recipient of the information in the agency's statement. However, it is not clear from the Act itself that the public is to have any active role in the consultation and comment process. Executive Order 11514 clarifies this together with CEQ guidelines which provide that agencies which hold hearings should make their draft statements available to the public at least fifteen days prior to the hearings. ${ }^{78}$

\footnotetext{
73 Anderson, Supra, n. 15 at 101.

74 The early view is illustrated by the decisions in Bucklein v. Volpe I ELR 20043 (N.D. Cal 1970) and Citizens to preserve Foster Park v. Volpe 1 ELR 20389 (N.D. Ind. 1971). In the former the court decided that environmental matters had been amply considered although a formal statement had not been prepared. In the latter the court held that although the statement did not conform to the requirement set out in the Act in 8 . 102 the defendant had complied to the extent possible.

${ }^{75}$ Calvert Cliffs' Coordinating Committee v. Atomic Energy Commisaion 1 ELR at 20436. Judge Wright at 20348.

70 Federal Water Pollution Control Act. s. 511 (c) (2) Amendments 1972 E.R. Federal Laws 71 : 5101.

1742 U.S.C. 4332.

78 CEQ guidelines April 23, 1971. 8. 10(e).
} 
The courts have also stressed the importance of the role of the public and have held that failure to give adequate and effective notice to the public is failure to comply with the Act.79

The public's role has not been confined however to commenting procedures. The public has made a much greater contribution through the citizen suit and class actions. The Administrative Procedure Act ${ }^{80}$ gives persons aggrieved by agency action, within the meaning of a relevant statute, standing to sue. Some commentators have argued that NEPA alone is sufficient to confer locus standi ${ }^{81}$; however it is not necessary to resolve this question in light of the Administrative Procedure Act.

In order to establish standing the plaintiff must allege injury in fact which he has or may suffer from the agency action. It is clear that such injury is not confined to physical or economic matters but includes injury to aesthetic, conservational or recreational interest. ${ }^{82}$

The injury alleged must be arguably within the zone of interests to be protected by the statute. This requirement highlights the two-edged sword effect of NEPA whereby industries have invoked NEPA as a delaying tactic. ${ }^{83}$

It is clear from the cases that once a plaintiff has established his standing he may then argue the broader public interest to substantiate his claim. It is clear, however, that the broad public interest is not sufficient to create standing in the absence of the satisfaction of the two tests enunciated above. ${ }^{84}$

In the litigated cases there have been few successful challenges to the standing of citizens and citizens groups as the federal courts have consistently confirmed the right of citizens to invoke NEPA's protection when environmental values are threatened by an agency's failure to comply with the Act. ${ }^{85}$

The claims made by citizens in suits under NEPA have centered on the key areas of the Act which have been so extensively interpreted by the courts. It has been asserted that the government has, or plans, to undertake a major action which requires an impact statement, and so such statement has been prepared or if one has been prepared that it is inadequate. There have been a few instances where the claim has been that although the procedural requirements have been met, the agency's decision is wrong in that they have ill balanced the environmental effects in their analysis; this latter claim is requesting the courts to judge agency action on the merits-a course not generally taken by the courts in their role in reviewing agency action. ${ }^{86}$

\footnotetext{
is Natural Resources Defense Council Inc. v. Morton 2 ELR 20029 (D.C. Air) The circuit court affirmed the earlier district court in holding that failure to adequately discuss alternatives rendered the final statement inadequate. The defendent had attempted to overcome the inadequacy by preparing an addendum in two days. The fact that the addendum had not been circulated for comment was sufficient to strike it down.

so Administrative Procedure Act. 10, 5 U.S.C. 1702.

n1 The arguments are advanced by Anderson, Supra, n. 15 at 16-17 and Yarrington, Supra, n, 45 at 11-13.

82 This was first established in Scenic Hudson Preservation Conference v. Federal Power Commission 1 ELR 20292.

83 The first instance of industry use of NEPA was the case of National Helium Corporation v. Morton 1 ELR 20157 (D. Kan. 1971). The issue has since become more troublesome and the more recent attempts to use NEPA in this way have been set out in Anderson, Supra, n. 15 at 40-44.

44 Sierra Club v. Morton 2 ELR 20192 motion for leave to amend granted 3 ELR 20173 (N.D. Cal. 1973).

*s The breadth of locus standi provisions is illustrated by SCRAP v. United States 2 ELR 20486 where the students merely alleged use of the forests, streams and mountains. It was held that the fact that specific environmental interests are shared by many "does not make them less deserving of legal protection through the judicial process."

so Ten courts have gone so far as to adjudge the actual merits of agency decisions although such a course has
} 
One aspect of the judicial process which could have precluded much citizen litigation would have been insistence on plaintiffs meeting stringent bond requirements. However, most courts have imposed minimal bond requirements and many no bonds at all. The wide public interest asserted by many plaintiffs seems to have influenced the courts in their stance and the attitude taken that: ${ }^{87}$

... [T] rigorously and consistently enforce NEPA than by any harm which could possibly result from delaying ... long enough to resolve the important legal issues presented by this suit.

\section{E. The Council on Environmental Quality}

This body, comprised of three within the Executive Office of the President, employs a staff of approximately 75 people of whom only about 20 to 25 are engaged in the impact statement process.

The Council's role is carried into three areas; promulgation of guidelines, general review of agency procedures, and investigation into specific problems.

The Council is not a reviewing body for the thousands of statements which have been prepared; it does collect the statements but its intervention in a particular area is not by way of regulation. It is not in the position of an independent Review Board but a general overseer and advisor to the President. In its annual Reports the Council assesses the state of the environment and promotes public awareness of environmental issues.

The main contribution of the Council in developing procedures under NEPA has been through issuance of guidelines.

The 1971 guidelines set up the impact statement process and introduced the concept of draft as well as final statements. This enabled the consultation and comment process envisaged in the Act to find meaning. The guidelines have often embraced legal interpretations of the various phrases of the Act in order to make agency duties more specific. For instance, in dealing with "major federal actions significantly affecting the quality of the human environment," the guidelines state that agencies should construe the phrase with a view to overall cumulative impact of the action proposed.

The guidelines set time limits for the commenting process of not less than 30 days and further provided that no action could be taken on a proposal less than 90 days after a draft environmental statement had been circulated. ${ }^{88}$

The guidelines urged agencies to utilize the process of public hearings whenever appropriate and to make a draft statement available at least 15 days prior to the hearing. ${ }^{89}$

The third set of guidelines issued on May 16, 1972 was issued in the form of recommendations. Many recommendations related to finding ways to consolidate numbers of impact statements into broader overall reviews. The Council recommended that agencies develop an inventory of effects likely to be involved in typical actions.

been advocated by at least one commentator Jay, D.E., Standing in Environmental Litigation: Let's get to the merits, (1973) 10. California Western Law Review 182. S. 101 gives some support to the theory that courts have a role in substantive review.

87 Natural Resources Defence Council v. Morton 2 ELR 20089 (D.D.C. 1971).

* CEQ Guidelines April 23, 1971, 8. 10(b).

ns Id. s.10(e). 
The main thrust of the other recommendations dwelt on developing an analysis of alternatives sufficiently detailed to permit independent and comparative evaluation of environmental considerations, and secondly, the development of an early notice system by which the decision to prepare an impact statement is announced as soon as possible.

On August 1, 1973 new guidelines superseding the previous ones were promulgated and came into effect on January 18, 1974. These guidelines were intended to "incorporate much of NEPA's legal evolution in the courts over the past two years and also reflect experience gained and lessons learned since 1971."90

The new guidelines reflect the Council's continuing concern that agencies should attempt to integrate NEPA requirements into their decision making and not tack them on as an after-thefact rationalization of agency action. The new guidelines also dwell on the problem of identifying secondary effects and means of dealing with predictions of secondary consequences, particularly in regard to population and energy. The problem of effectively ensuring public participation in the process also gained extensive attention and the guidelines go so far as to suggest that agencies should automatically send copies of statements to interested public organizations and individuals and to experiment with methods of public input ranging from "informal, unstructured contacts with community and environmental leaders to more formal panels of advisors on NEPA issues or clearing houses for citizen inputs into the impact statement commenting process." 91

\section{F. The Federal Agencies}

As all federal agencies are required to abide by the mandate of NEPA it is instructive to look at the response of those agencies to the Act. By examining the way in which agencies have altered their procedures in order to facilitate decision making which reflects the spirit of the Act it is possible to adjudge the impact of the legislation. It is not possible to examine the procedure of every agency but for the present purpose it is sufficient to look to some of the changes which have materialized in the processes of the Atomic Energy Commission which can be adjudged as fairly typical.

The Environmental Protection Agency like other agencies is required to file environmental impact statements.92 Unlike other agencies it has special responsibilities to review and comment on other agencies, statements. Section 309 of the Clean Air Act ${ }^{93}$ creates this duty and further provides that the administrator's comments be made public. If the administrator finds the impact of the proposed action to be environmentally unsatisfactory he must refer the matter to the Council on Environmental Quality. One commentator ${ }^{94}$ has noted that EPA took up this task rather tardily and that not until early 1972 did it publish guidelines and give notice of the availability of the comments. As EPA review comes more fully into play, it is apparent that the procedure will

90 Environmental Quality: The Fourth Annual Report of the Council on Environmental Quality 234 (1973).

91 Id. at 236. The problems connected with the timely release of information to the public has been of constant concern to CEQ over the past four years. On May 15, 1973 it issued a memorandum to agencies suggesting that rather than rely on National Technical Information service to meet public requests for draft statemento, agencies should, on their own account, make sufficient number available in order to get public input with as little delay as possible. $3: 5102$ Monitor (1973).

92 Apart from the exemption applying to its water quality programs see $n .76$.

93 The Clean Air Act 42 U.S.C. 1857.

24 Anderson, Supra, n. 15 at 233. 
give EPA an important opportunity to counterbalance the perceptions of development oriented agencies in their dealings with the impact satement process.

The development of agency procedures can be seen in the Atomic Energy Commission. In this agency the case of Calvert Cliffs Coordinating Committee v. $A E C^{95}$ provides a convenient marker from which to look both back and forward. ${ }^{96}$

The main concern of AEC is the licensing of nuclear power plants, AEC's regulatory responsibility stems from the Atomic Energy Act 1954 which requires the AEC to provide reasonable assurance that peaceful uses of atomic energy do not result in undue risks to public health and safety. The licensing procedure commences with the issuance of a construction permit and prior to NEPA the application was primarily concerned with safety matters.

After the passage of NEPA the AEC revised its procedures to reflect the NEPA requirements. In addition to safety measures applicants were required to submit environmental reports which were utilized by the Commission in preparation of its statements under NEPA. The AEC took the position that it could accept certification from states regarding water quality standards and did not have to independently consider them.

AEC procedures provided that no environmental issues could be raised at hearings for which the hearing notice was issued prior to March 4, 1971.

In 1971 the test to AEC's response to NEPA was made in the Calvert Cliffs case in which the plaintiffs contended that the response was inadequate. The court agreed.

The court held that non-radiological environmental considerations must be examined even if licencing proceedings are uncontested and that the licencing Board was required to independently evaluate the final balance among conflicting factors. Secondly, the Commission was required to consider NEPA requirements for all facilities for which permits were granted after January 1, 1970. Thirdly, the AEC could not rely on water quality certifications but must make its own assessment and finally it must also consider ${ }^{97}$ environmental factors for permits issued prior to the passage of NEPA.

The AEC responded to the decision by enlarging its staff to clear the backlog of reviews required by the decision. It called a moratorium on licencing for 14 months and amended its procedures to adopt the requirements set forth by the court for public involvement and independent assessment.

The new procedures have caused the AEC to be:98

... much more conscious of the environment, and knowing the degree of scrutiny their projects will undergo when submitted to the AEC for authorization to proceed, they [the utilities] are making initial design decisions that reflect a sense of environmental values.

The case of the AEC is illustrative of many agency responses to

3s Supra, n. 75.

- This analysis relies on the account given by R. Purple, Senior Environmental Project Manager Director of Licensing U.S. Atomic Energy Commission, Proceedings, Supra, n. 16, $25-45$.

97 This part of the decision has been overruled by statute. Federal Water Pollution Control Act amendments 1972 see n. 76.

90 Purple, Supra, n. 16 at 45. 
NEPA. At first a timid reordering, then a major reorganization as an after-the-fact reassessment caused by litigation. It illustrates how little impact NEPA might have made without the forceful intervention of the courts to oversee the changes.

\section{G. NEPA to Date-Problems and Prospects}

The discussion to date indicates that NEPA has received much attention since its enactment. The question to consider now is whether the net benefits have outweighed the net costs of its enactment and its effects on decision making in the agencies to which it applies.

In dealing with NEPA's critics a frequent criticism has been the lack of attention given by reviewing courts to recommendations or reports on proposals for legislation and policies. ${ }^{99}$ Litigation has concentrated on "any other federal actions." As previously discussed, the public have been the principal plaintiffs in court proceedings; it is clear that their actions tend to materialize as the threat to the environment evolves. The focus of their actions is related to particular projects as it is not until a project begins to materialize that the public becomes aware of the inherent threat. It would seem that lack of awareness precludes public input at the report or policy stage. It has also been suggested that lack of legal remedy would preclude suit at this point even if the information was available. ${ }^{100}$

It has been suggested that on the whole, statements have tended to be justifications of agency projects and have therefore fabricated or overvalued benefits in an attempt to sway the balance. It has been said that: ${ }^{101}$

NEPA litigation has been primarily successful in stimulating after-the-fact rationalizations which are examined less by agency decision-makers than by agency lawyers, whose job is to ensure that the agency's environmental review can survive legal challenge.

Some see the only result of NEPA being the creation of a procedural paradise for intervenors who wish to delay progress in the name of environmental protection. ${ }^{102}$ The administrative difficulties in implementing NEPA have resulted in considerable paperwork and economic costs as programs have been slowed or halted. Against these difficulties one must view some positive results of the Act to see a more even picture.

The task which NEPA set for the federal agencies was colossal. It required the agencies to completely revitalize their procedures to consider facets which hitherto had been outside their realm. The process of change was necessarily a slow one as new perceptions and procedurt $:$ : vere adopted. It would seem clear that several positive results can be seen.

NEPA has broadened agency decision making in several ways. All agencies have been required to consider environmental matters. This has widened agency mandates in most cases and given them a jurisdiction which was not previously present. It has required agencies to consider alternatives outside of agency missions which generally are outside the agency's power to implement.

92 Anderson, Supra, n. 15 at 125-133. He observes that only 118 draft and 45 final statements concerning proposed legislation had been submitted by November 30,1972 , the majority concerning environmentally protective legislation. If all proposed legislation produced impact statements approximately 800 statements would be submitted during each session of Congress.

$100 \mathrm{Id}$. at $129-30$.

101 Id. at 288.

102 Holifield, Chairman of Government Operations Committee, National Journal, 26 February 1972. 
NEPA has opened the doors to outside scrutiny into agency decision making and created a duty of full disclosure. By requiring agencies to consult with and obtain comments from other agencies prior to preparing the detailed statement and by enabling the public to see and comment upon the draft statements, a new dimension has been added to agency procedures. The full disclosure requirements have made agencies more sensitive to public interests and more conscious that they must look closely at their decision-making procedures if they are to avoid litigation. The change in outlook is evidenced by new agency procedures which incorporate these new areas of concern.

To date much attention has focused upon projects which were in the pipeline before the Act was proclaimed. The retroactive effect given to NEPA by judicial interpretation had caused part of the backlog and administrative delay. It has even been suggested that the courts have required an impossible task of the agencies in this respect. ${ }^{103}$ Because a lead time of at least ten years exists between proposal and project the retroactive aspects will be present for several years. In order to mitigate the inequitable consequences of this position and to prevent a narrow perspective developing too early in the planning stage, it has been suggested that the development of a two tier impact statement procedure should be investigated. ${ }^{104}$

The two tier procedure would involve the development of a broad statement on policies or proposals which would be subjected to scrutiny before any commitment to a particular project was made. Such a development would serve several useful functions.

First, it has been previously noted that the main thrust of review has dealt with projects and that as the public are the major scrutineers they are limited to challenging projects rather than proposals, either because of lack of awareness or lack of legal remedy at an earlier stage. The two tier system would afford the public an opportunity to state its preferences at an early stage of a proposal before any committments were made or alternatives precluded.

Second, the present requirement of the Act that agencies consider alternatives not necessarily within their jurisdiction, while widening the agency focus, does in practice present several problems. The existence of a mission-oriented agency presupposes the efficacy of the mission, and the perception of those involved with the agency will also reflect this. The judicial interpretation of NEPA requires that agencies not only broaden their perspectives, but in many cases the unrealistic requirement that they question the first principles upon which their very existence relies has been thrust upon them. It would seem apparent that:105

[T]o select among alternatives, one must be able to measure their relative merits in terms of some standard or objective, the validity of which is presumed. Such a standard or objective represents in itself a choice among alternatives that has presumably been made at an anterior point in time perhaps at a higher governmental level, on the basis of another and more general norm.

Proposals for agency action generally filter through from preordained statutory goals. The agency will not be in a position to compel

103 Murphy, The National Environmental Policy Act and the Licencing Process: Environmentalist Magna Carta or Agency Coup de Grace, (1972) 72 Columbia Law Roview, 963.

104 Anderson, Supra, n. 15 at 108, 122, 177, 220.

10s Cramton and Berg, On Leading A Horse to Water: NEPA and the Federal Bureaucracy, (1973) 71 Michigan Law Review, 511 at 529. 
the acceptance of alternatives or approval by another government agency if it should deem another to be more appropriate for the task. Thus if an agency does reject a project on environmental grounds the matter is stymied, for the agency cannot secure the development or acceptance of the more preferable alternative which it has identified. NEPA does not enable an agency to do this and it is clearly the task of a higher echelon to so direct projects to missions after alternatives have been considered in the broader context. An earlier assessment at the higher level could achieve this and foreclose the present problem of requiring agencies to question the very principles for which they were established. Second, the present situation which requires agencies to consider alternatives outside their jurisdiction also involves them in areas outside their competence. The comment process overcomes this to a degree but the problem of agency perception of its mission makes it impossible for an agency to consider projects in the same manner as a decision body without limited mission goals.

Third, the broadened perspective required agencies to increase their technical staffs to employ personnel from diverse disciplines to achieve an interdisciplinary team. The initial lag in budgeting and appropriations resulted in the first major recruitments being delayed until July 1972. ${ }^{106}$ Until that date the burden was borne by existing personnel, or by diverting funds from other sources. The two tier process would to a degree centralize the data gathering process so that agencies would be able to utilize this data, with the result that expertise could be utilized more uniformly and at a high standard.

The development of the two tier system would greatly further the impact of NEPA and relieve the agencies from some of the unrealistic matters that have fallen to them. An examination of NEPA at work to date indicates that its greatest impact has been in the areas where an effective action forcing mechanism exists, i.e. the citizen suit. The areas of the statute obscured from action-forcing mechanisms have remained relatively dormant with the result that the Congress has been able to side-step its responsibilities in a manner not permitted of its agencies.

It is to be hoped that the Congress will review its role and take upon itself a more responsive attitude which will be reflected in the opening of its decision-making to the same scrutiny as that of its agencies.

Despite some difficulties in working with NEPA, it has clearly had a considerable impact in the four years of its existence. It is also clear that the statute must be read in the context of the institutions which form the backdrop against which it operates. Whether NEPA as it stands could be transplanted successfully into a Parliamentary system depends on the workings of the system with which it would have to interact. A comparative analysis of the features of the Congressional and Parliamentary systems is the subject of the next section.

\section{ENVIRONMENTAL ASSESSMENT LEGISLATION AND THE PARLIAMENTARY SYSTEM}

\section{A. Introduction}

The role of the courts in the United States has contributed in large measure to the success of NEPA. Would Canadian courts fulfill a similar function? There are several features of the Parliamentary system which 
indicate that the answer will be in the negative. Because of the differences in the governmental structure, procedures which have enabled citizens to call on the courts to intervene in the United States have no Canadian counterparts. These will be dealt with first.

\section{B. Procedural Differences}

The vigorous enforcement of NEPA provisions in the United States has largely been as a consequence of citizen suits. More liberal locus standi requirements do not create the same stumbling block to U.S. litigants as do stricter requirements in Canada.

Where private parties contest the legality of administrative action the U.S. Administrative Procedure Act ${ }^{107}$ provides that a plaintiff must be aggrieved by agency action within the meaning of the relevant statute. To be aggrieved a plaintiff must ailege that he has or will suffer injury in fact. Injury in fact extends beyond pecuniary injury to aesthetic, conservational or recreational interests. The second requirement is that the plaintiff be arguably within the zone of interest protected by the statute. Interpretations of NEPA have held both citizen groups and industry representatives to be within the zone, so long as both injury and interest are established by the one plaintiff. The courts have given little weight to flood gate arguments which favour limiting standing:108

We do not share the fear of some earlier decisions that liberalized concepts of standing to sue will flood the courts with litigation. However, if that should be the price for the preservation and protection of our natural resources and environment against uncoordinated or irresponsible conduct, so be it. But such seems improbable. Courts can always control the obviously frivolous suitor.

In Canada the United States Administrative Procedure Act has no federal counterpart. The rules for standing are stricter and more technical. Without specific provisions in the statute to increase the eligible litigants, plaintiffs must allege, not merely that they will or have suffered injury in fact, but that the injury they allege is different from that suffered by the public in general, or that it relates to injury to a private right. Traditionally the Attorney General is entrusted with protecting public rights. Recent cases have displayed a more liberal trend where the Attorney General has declined to take the initiative. In such circumstances, the refusal of the Attorney General to take up the cudgels could result in unconstitutional behaviour passing unchecked. As the public has a right to expect constitutional behaviour from its representatives then, depending on the justiciability of the issue and the nature of the legislation, it now appears that a plaintiff who alleges no greater interest than the rest of the public will be granted standing. If this were not permitted ultra vires action may go unchecked. This was the reasoning behind two recent cases. ${ }^{109}$ However, in cases where persons or classes of persons who are more adversely affected than the general public can be identified, it may well still be the case that the existence of such persons would preclude other plaintiffs without such interest.

More generous standing is granted a plaintiff seeking one of the prerogative writs. In England there have been two recent cases ${ }^{110}$ where

1075 U.S.C. 1702

10. Izaak Walton League v. Macchia. 1 E.L.R. 20300 at 20303 (D.N.J., 1971).

109 Thorson v. Attorney General [1975] S.C.R. 138. The Nova Scotia Board of Censors and the Attorney General for Nova Scotia v. McNeil, S.C.C. May 20, 1975, as yet unreported.

110 R. v. Metropolitan Police Commissioner, Ex parte Blackburn [1968] 1 ALL E.R. 764. The application for mandamus did not succeed but the court left open the question of locus standi, and did not discuss it, and proceeded 
standing has been granted to a stranger espousing the public interest. The following comment may indicate a similar trend for Canada.111

I think that the argument for standing in the present case is fortified by analogy to the cases on certiorari and prohibition which even in a non-constitutional context, have admitted standing in a mere stranger to challenge jurisdictional excesses, although the granting of relief remains purely discretionary.

That the discretionary element may deprive a plaintiff of remedy is illustrated by a recent Manitoba case where the plaintiff was given standing but denied an injunction on the ground that he failed to discharge the onus of proof under the test of balance of convenience. ${ }^{112}$

If the standing hurdle is overcome, the heavy burden of discharging the onus of proof may be a greater stumbling block. In addition the summary nature of prerogative writ procedures, where evidence is by affidavit, often camouflages disputes which would only surface if discovery of documents and interrogatories were obtained. ${ }^{113}$

In the absence of statutory requirements for a written record or the imposition of mandatory duties upon public officials, the scope for use of prerogative writs is limited. As presently enacted NEPA is silent as to standing and it appears that, despite more liberal interpretation of the rules in Canada, the vigorous public role in the United States would not occur in Canada.

Provisions for access to information also differ in Canada. The Freedom of Information Act (1966) ${ }^{114}$ in the United States confers on the citizen a legally enforceable right of access to government files and documents. It places the burden on the government to justify the withholding of documents when they have been requested, and gives to anyone who is improperly denied access the right to injunctive relief.

There is no equivalent legislation in Canada and secrecy is generally the rule. ${ }^{115}$ There are several statutes at the Federal level which provide that the government may require information from various persons, but there is no provision in any statute which requires the government to make its information public. ${ }^{116}$

Governments feel that they are more able to use the information which they have than is the public and that they are competent to decide which information the public should and should not have... The investigations following leaks have re-enforced the suggestions that the Federal Civil Servants take the oath of office and secrecy very seriously. It is disturbing that "office" and "secrecy" are almost synonymous. ${ }^{117}$

If general secrecy is the rule, the result is that all information remains secret unless the Minister expressly approves its release. The burden

to the question of the Commissioner's duty. $R$. v. Metropolitan Police Commissioner, Ex parte Blackburn and another (no. 3) [1973] 1 ALL E.R. 324. Although the application for mandamus was dismissed the ques. tion of locus standi of the plaintiff was not raised at all. Each of the three judges commented on the public service done by the plaintiff in bringing attention to the issue.

"Thorson v. A.G., Supra, n. 109.

112 Stein v. City of Winnipeg (1974) 48 D.L.R. (3d) 223.

113 Barnard v. National Dock Labour Board [1953] 2 Q.B. 18. Although this case related to a declaration it does illustrate the point that, if discovery of documents had not been permitted, the crucial point which caused the case to be decided in the plaintiffs favour would not have emerged.

1145 U.S.C. 552.

115 The problem of secrecy in government has been examined by Abel, Administrative Secrecy (1968) 2 Canadian Public Administration, No. 4, 440. Knight, Administrative Secrecy and Ministerial Responsibility (1962) 28, Canadian Journal of Economics and Political Science, 114.

116 The Clean Air Act, S.C. 1971 c. 47. The Fisheries Act, R.S.C. 1970 c. F.14. Canada Water Act, R.S.C. 1970 (18t Supp.) c. 5. Arctic Waters Pollution Prevention Act, R.S.C. 1970 (18t Supp.) c. 2.

117 Thompson Dixon, "The Scientist Civil Servant and Public Participation" G.C. Morley (Ed.), Ask the People, Westwater Research Centre and Environment Canada, (1972). 
that this practice would place on a potential plaintiff in a NEPA action would be enormous. To secure greater access to information, specific provisions would have to be enacted to reserve the current situation.

Many court actions in the United States are presented as class actions. ${ }^{118}$ In Canada the scope for use of class actions is very limited. If a plaintiff with the necessary locus standi to seek injunction can be found, the question of bonds for preliminary injunction is likely to be prohibitive to most litigants, as is the cost of the litigation itself.119 These procedural differences were recognized by the Canadian Bar Association, which resolved at its annual meeting in September 1973:120

That the Canadian Bar Association supports public participation in the planning and approval of projects that have a significant environmental impact and in the enforcement of regulations designed to protect the environment and recommends that:

(a) every project having significant environmental impact be preceded by an environmental impact study, paid for by the proponent of the project and other information obtained through public funds be made available to the public; and

(b) any individual or groups have the status to object to any such project and that upon such objection, a mandatory public hearing be held before a government approval or licence is granted; and

(c) individual or groups, with the leave of the court, on his or on their own behalf or on behalf of the public have the status before all courts or administrative tribunals to review such project or enforce any governmental regulation without demonstrating a special interest or damage.

If transmitted into appropriate legislation, such a resolution would solve the difficulty of locus standi, remove the need to rely on prerogative writs, remove the limitations on class actions and make information available to the public.

If these and other procedural differences can be overcome, does NEPA fit into the Parliamentary system? Does it give Canadian courts the necessary tools to bring forth the response which has taken place in the United States? These questions involve a study of the nature of legislation and the nature of statutory interpretation in Canada.

\section{Parliamentary Legislation}

There are three branches of government in both the United States and Canada. These branches are the legislature, whose function it is to make the laws, the executive, whose function it is to carry out the laws, and the judiciary, whose function it is to interpret and enforce the laws.

The Articles of the American Constitution embrace the concept of separation of these powers. One commentator expresses it thus:121

It has long been recognized by legal scholars that the basic forms of American government reflect England at the close of the 17th century rather than England of 1776 . The distinction is critical because while we adopted the Whig principle of legislative supremacy for policy determination, we rejected the merging of legislative, judicial and executive power that Walpole accomplished in the 18th century England and that stifles the Mother of Parliaments to this day. Instead we kept to the older Whig princi-

118 In the United States class actions are governed by the revised Federal Rules of Civil Procedure, 1966, Rule 23 which provides that a class action is maintainable where: the class is so numerous that joinder of all members is impracticable; there are questions of law or fact common to all; claims or defences are typical and the representative parties fairly adequately protect the interest of the class.

119 The problem of legal costs is discussed by Fraser and Anthony, "Litigating Environmental Matters: A survey of the Problem", Ask the People, Supra, n. 117 at 98-99. A good example is provided by the Ontario case of Green v. The Queen in Right of the Province of Ontario, et al. [1973] 2 O.R. 396 where the costs to the unsuccessful plaintiff have been estimated at $\$ 4000$. This is quoted in Estrin and Swaigen, Environment on Trial, 320 (1974).

${ }^{120}$ Quoted from Canadian Environmental Law News, Vol. II., No. 5, October 1973, 127.

121 Haefele, Representative Government and Environmental Management, 5 (1974). 
ple of the independence of the common law and an independent judiciary as the interpreters of Constitutional law.

While one may not agree that the English Parliament has been stifled by her system, it is clear that the American doctrine of separation of powers has resulted in legislation different in nature from that enacted by Parliaments where executive and legislative functions have been merged. The Canadian government, like the English government, has an executive which represents the majority in the legislature. Thus the legislation of the Canadian Parliament is the result of the will of the executive who is supported by a majority in the Parliament. In contrast, the United States Congress may enact legislation which is opposed by the executive. Such a situation is not possible in the Canadian system.

In Canada, legislation commences in government departments; a draft is submitted to Cabinet, and after obtaining Cabinet approval the bill goes to Parliamentary Counsel. ${ }^{22}$ When the bill is introduced to the House it is done so with the knowledge of Cabinet's approval, and the principles of Cabinet government virtually ensure that the bill will pass into law with the vote of the majority party. Any balancing of competing demands is attended to in the secrecy of the Cabinet, and generally the competing demands are those defined by the majority party, not by the opposition. The latter's role is limited to criticism in the House. In the face of a government majority this criticism is not a strong factor in influencing the content of legislation.

In the United States the executive is quite separate from Congress so that: ${ }^{123}$

neither the President nor any member of his Cabinet can sit in the legislature. The legislature is cut off from any direct access to the information and experience that the executive accumulates and the executive cannot participate directly in the framing and passing of legislation.

With no counterpart to the theory of Cabinet responsibility, and with much weaker party cohesion, the American system of legislation gives more opportunity for accommodating conflicting demands and interests in broad policy statements acceptable to diverse interests.

Legislation is introduced to Congress by means of standing committees. There are standing committees for each of the important recurring subjects of legislation. Each committee comprises members representing the parties in the proportion that each party is represented in the House. ${ }^{124}$ Although a majority for one party is assured in each committee there is no strong party cohesion on the lines apparent in the Canadian Parliament. Because legislation is prepared by a committee representing all parties, and because individual members in the House are not constrained by party lines, legislation will reflect more diverse interests in the American system than in the Canadian. Because the executive is not represented in the legislative process, it may be possible that Congress will enact laws not popular with the executive; this is not possible in a Parliamentary system.

In the Parliamentary system, a degree of control of the executive is maintained through the legislature to an extent not possible in the Presidential system. The extensive regulatory and administrative func-

\footnotetext{
122 Driedger, The Composition of Legislation, xvii-xviii (1957).

123 Corry and Hodgetts, Democratic Government and Politics, 334 (3rd ed. 1964).

124 ld. at 199.
} 
tions of government, which have multiplied since the Second World War, have resulted in substantial delegation of powers from legislature to executive. The aggrandisement of the Executive through administrative tasks has occurred in both countries.

The principle of ministerial responsibility implies that a Minister of the Crown is answerable in Parliament for the acts of his department. Thus the fusion of executive and legislative functions was intended as the means of controlling the departments of the administration through ministerial accountability in the House. As government activity has increased, the feasibility of maintaining that the Minister is responsible for the acts of his department has become somewhat strained. Nonetheless it would seem that the possibility of being questioned in the House is a powerful restraint on maladministration. The link between executive and legislature as a checking device also entails that the role of the courts is to ensure that the executive acts within the powers given to it by the legislature. As a constraint is provided (at least in theory) by the legislature, it has never been thought proper for the judiciary to interfere with the manner in which powers were exercised, so long as they were within the legal limits of authority.

By contrast the separation of powers in the United States makes the agencies of the executive quite independent of the legislature. Basically, the administrative processes of the United States government are ordered by ten departments in the executive. These departments are subdivided into agencies and bureaux. The Congress legislates by pronouncing broad policy objectives and the executive uses its administrative processes to expound those objectives in innumerable rules and regulations. ${ }^{125}$ The delegation of rule-making to independent agencies raised problems concerning control of agency action or inaction. The independence of agencies in rule-making led eventually to the enactment of the Administrative Procedure Act, which regulates agency rule-making functions and prescribes the procedures to be followed. It applies alike to formal and informal procedures and rules, ${ }^{126}$ and provides the link to enable the judiciary to control agency action which, in the absence of statute, would be limited to constitutional issues. Mindful of the proliferation of agency regulation, the courts have taken the role of overseer in a very positive manner.

Although both Canadian and United States courts are concerned with jurisdictional questions, the Parliamentary system appears to give the courts a more restrictive role than the courts of the Congressional system, where legislative and executive functions are separate. The structure of government also influences the nature of the legislation; that of the Congress reflects different influences from its counterpart in the Parliamentary system.

For example, part of Title I of NEPA is a declaration of national policy which enunciates the purposes of the legislation. In so far as Title I relates to the federal agencies, it sets forth, in very broad terms, what Congress envisaged that agencies needed to do so as to implement the policy set forth in the Title I.

Generally, legislation from the Canadian Parliament is cast in different form. Preambles stating, or purporting to state, the general ob-

125 Id. at 518.

128 The rule-making procedures of the Administrative Procedure Act do not extend to interpretative rules. 
jects or purposes of statutes are rarely seen in modern Canadian legislation. It has been observed that they are: ${ }^{127}$

... used in statutes dealing with a subject matter that is normally local and therefore within provincial jurisdiction, but by reason of exceptional circumstances has become of national concern and therefore within the jurisdiction of Parliament. The purpose of the preamble is to recite the exceptional circumstances.

The same writer observes that a general statement of purposes is "hardly helpful" in interpretation, and if the preamble is intended to have legal effect, it should be inserted in the Act itself, and if not it should be restricted to insertion in the minister's speech when the bill is introduced. ${ }^{128}$ It will be recalled from previous discussion that American courts have been aided by the declaration of national policy in Title I of NEPA which sets forth the purposes of the Act. It appears doubtful that a similar provision would receive any attention by Canadian courts.

The substantive sections of statutes first set up the administrative machinery necessary to outline the framework for action, and second, set forth rule-making machinery. Parliament could create an independent body akin to the Council on Environmental Quality, and it could also make provision for all departments to initiate procedures for assessing environmental impact. The crucial part of the legislation is the rulemaking provision. The general practice is for the legislature to delegate to the executive the implementation of this part. This is either done by giving discretion to make regulations to a Minister or by Order in Council. This vital stage differs markedly in result from its American counterpart.

NEPA provides for the CEQ to implement guidelines for agency compliance with the purposes of the Act. Guidelines are informal procedural rules which, in the United States, are binding upon agency action in the same manner as regulations or other forms of delegated legislation.

In Canada, informal administrative guidelines, policy statements and departmental memoranda have been treated as administrative acts outside the purview of judicial control. To enact legislation in Canada which provided for the details of assessment procedures to be set forth in guidelines would not result in the same degree of judicial control as in the United States.

The success of NEPA in changing the decision-making practices of agencies has been largely dependent upon the availability of the court as a forum to require strict compliance. The court has framed its requirements by reference not only to the terms of the statute but also to the guidelines which have been promulgated by the CEQ. As a Canadian statute which made provision for guidelines would not give the court power of enforcement, a statute like NEPA would not permit a Canadian court the same role as in the United States. The legislation necessary to produce the same result in the Parliamentary system may have to be cast in form different from NEPA.

\section{Conclusion}

It is possible for a Canadian statute to clarify the rules necessary to ensure that the policy would be effectively enforced. This could be achieved by substantially delineating discretionary powers left to the ex-

127 Driedger, Supra, n. 123 at 93. Canada Water Act, RSC 1970, C.5 preamble illustrates this well.

12s $\mathrm{Id}$. at 95. It should be noted, however, that the Interpretation Act declares that the preamble is part of the Act. 
ecutive by Parliament, clearly setting forth the duties incumbent on agencies and the rights conferred on citizens to see those duties adhered to. The problem of determining which matters are substantial and in need of statutory enactment, and which are merely procedural, is one which Parliament is too often willing to abdicate to the executive. One writer has noted that: ${ }^{129}$

... by withdrawing from Parliamentary consideration all matters save the need for power such a Bill clearly does not permit the representative body to function in the way it is fitted.

Where legislation is required to improve decision-making it seems trite to emphasize the inadequacy of legislation requiring agencies to improve their decision-making by self-regulation. Legislation must incorporate provisions for enforceable procedural duties to prepare impact statements, to hold public hearings, to make information available and confer a right in any interested person to ensure that the procedural requirements are met.

For many tasks of modern government, legislation has been the instrument to create the framework for action, while the action is generally left to the executive and is not spelled out by the legislature. General legislation is inadequate to improve agency decision-making processes. Improving decision-making procedures is not the customary function of legislation; therefore, stating a purpose, setting up the machinery, and letting the departments decide how the purpose is to be fulfilled, is inappropriate.

The purpose of legislation to regulate decision-making procedures is to regulate the part of government activity hitherto permitted to be dealt with by executive action. For the Parliament to set up a workable procedure, it cannot shirk the responsibility of stating the manner in which decision-making is to proceed. To say that environmental considerations will be an integral part of agency decision-making, and to leave the procedures to Order in Council, is tantamount to a contradiction. Because the executive and the legislature are fused, the failure of Parliament to clearly express itself will make any proposal ineffectual. In the United States, Congress sets forth its policy and directs the executive to implement it. The Canadian Parliament, because of the fusion of executive and legislature, cannot rely on this process, and the legislature must decide what will be required of agencies, and not relegate this back to the executive. If procedures are to be adopted, the standards have to be decided and guarantees have to be stipulated which will ensure that the procedural requirements are followed. In the United States the courts have, in many cases, answered the policy questions left vague by Congress or the CEQ. The search for congressional intent through legislative history and broad statements of policy is not a course followed by Canadian courts who, given the task of interpretation, confine themselves to seeking the meaning of statutes through the words which Parliament has enacted.130

Environmental impact assessment legislation will require agencies to revise their current practices in many ways. As agencies change slowly, and sometimes unwillingly, the effectiveness will be dependent on clear

\footnotetext{
${ }^{129}$ Griffith, The Place of Parliament in the Legislative Process, (1951) 15 Modern Law Review 279 at 296.

1.30 It has been suggested that courts in the United States have tended to be more concerned with policy because of their concern with constitutional matters. The Interpretation of Statutes. Law Commission Report, H.M.S.O. No. 21, para. 18.
} 
requirements which can be enforced. It is therefore necessary that the Parliament reassert its full powers by providing statutory guarantees of procedural compliance in the body of the statute, and does not avoid the vital issues by leaving to the Executive the very problem which has arisen from this practice in the past.

NEPA is a useful model for those entrusted with developing environmental impact assessment procedures in Canada. There are many lessons to learn from NEPA, and perhaps the most salutary is the demand for the public to be heard. In the absence of another forum the court has been used, and used successfully. Is that the route appropriate in Canada? Litigation polarizes the parties in bitter conflict. An assessment process should attempt to evaluate conflict in an open forum, weighing one set of interests against another. Essentially the final decision is a political one, not a judicial one. The political process can be improved by an assessment technique which allows the public to be heard, to be informed, and to participate. If the assessment process embodies these features, the goal of impact assessment will be more readily achieved than it would by abdicating political functions to the judiciary. 